\title{
Deep Disagreements on Social and Political Justice: Their Meta-Ethical Relevance and the Need for a New Research Perspective
}

\begin{abstract}
This article starts off with a historical section showing that deep disagreements among notions of social and political justice are a characteristic feature of the history of political thought. Since no agreement or consensus on distributive justice is possible, the article argues that political philosophers should - instead of continuously proposing new normative theories of justice - focus on analyzing the reasons, significance, and consequences of such kinds of disagreements. The next two sections are analytical. The first sketches five possible reasons for deep disagreements among notions of social and political justice. The second discusses the meta-ethical relevance of the lack of consensus on justice and rejects ethical realism and cognitivism based on the argument from deep disagreements.
\end{abstract}

\section{The need for a new research perspective on social and political justice}

Following Neo-Kantians like Jürgen Habermas and in particular John Rawls, leading contemporary political philosophers aim at some form of consensus or rational agreement on justice. ${ }^{1}$ Rawls conceives of this as a consensus concern-

For their astute and helpful comments on this article I thank Thomas Schramme, Stephen Snyder, Andreas Urs Sommer, and Bertjan Wolthuis.

1 Nussbaum understands her capabilities approach as "a partial theory of social justice" that "aspires to be the object of an Overlapping Consensus" (2011, pp. 40, 93, cf. pp. 79, 91). In line with Ronald Dworkin, Will Kymlicka even claims that all contemporary theories of justice agree on "equality as a value" (2002, p. 4; cf. Haus in this volume). In several of his writings, Jürgen Habermas holds that unimpeded discourses and arguments based on communicative reason are generally able to solve disagreements and lead to consensus in moral issues (1991; cf. Wolthuis in this volume). Like discourse, consensus is a central value of modern proponents of deliberative democracy who believe that deliberations ideally aim at rational agreement. In response to this, Jeremy Waldron states "that in the real world, even after deliberation, people will continue to disagree in good faith about the common good, and about the issues of policy, 
ing an "initial choice situation" for principles of justice, as a rational agreement on which principles to choose, or as an "overlapping consensus" that a pluralist society should reach with regard to a political conception of justice (1971, §4, $\S \S 20$ ff.; pp. 18, 118 ff.; 2005, IV §§ 1-8, pp. 133-172). For Rawls, citizens' consensus on principles of justice is an essential feature of a "well-ordered society" (1971, § 1, p. 4 f.; 2005, I § 6, p. 35). However, the notion that a consensus on social and political justice could be achieved was questionable from the start. This was made evident by Robert Nozick's immediate and strong disagreement with Rawls's fundamental moral conviction that the inequalities of natural endowments are undeserved and call for social redress or compensation (Nozick 1974, pp. 168f., 225, 228). Likewise, no agreement can be reached about Rawls's claim that individuals are equal as moral persons (Rawls 1971, pp. 19, 505). Going back to Aristotle, John Kekes argued that people who habitually harm others have a lower moral worth than those who habitually do good (Kekes 1990, pp. 121-123). From this perspective, Rawls's rationalist creed that all persons can be convinced by the same arguments and must therefore reach a rational consensus on principles of justice becomes highly questionable (Rawls 1971, p. 139).

This article argues for the need of a shift of the research perspective on social and political justice. Its first aim is to show that no consensus on justice is possible. The article demonstrates that many convictions and conceptions concerning social and political justice are not only opposed to each other, but that there exist deep disagreements between them. Deep disagreements are disagreements that cannot be resolved through the use of reasons and arguments (cf. Fogelin 2005 , pp. 8, 11). ${ }^{2}$ As a consequence of deep disagreements on social and political justice, political philosophers should redirect their efforts. Instead of continuously proposing and defending new normative theories of justice, they ought rather research the reasons, significance, and consequences of such kinds of disagreements and find out how to cope with them. In order to progress, innovative political thought has to move beyond the idea of the consensus. This move is also necessary because many political conflicts are caused by or can be derived from disagreements on social and political justice that can - in the worst cases lead to violent conflicts and even civil wars. ${ }^{3}$

principle, justice, and right which we expect a legislature to deliberate upon” (1999, p. 93, cf. p. $91 \mathrm{f}$.).

2 Fogelin's 1985 article sparked controversies on deep and peer disagreements. For a summary of the debates and literature on the epistemology of disagreement see Siegel 2013.

3 The arguments of this article proceed mainly on the conceptual level. However, this level is closely linked to the level of "practical politics". Philosophical conceptions of social and polit- 
Insights regarding deep disagreements on social and political justice can be found, as early as 1984, in Dagmar Herwig's systematic study on justice - her "Habilitationsschrift" - that received little attention (Herwig 1984). Herwig's study shows that two opposing models of justice - "equal treatment” (Gleichbehandlung) and "equalization" (Egalisierung) - can be traced throughout the history of political thought. ${ }^{4}$ In Justice and Interpretation (1993), Gorgia Warnke questioned the "ideal of political consensus" from the perspective of the "hermeneutic or interpretative turn" in political philosophy and argued that there are “disagreements between equally well-justified interpretations” (Warnke 1993, p. VIIf.). ${ }^{5}$ Also Stuart Hampshire's Justice is Conflict and Jeremy Waldron's Law and Disagreement depart from disagreements on justice and the divergent conceptions of justice prevailing in society (Hampshire 1999; Waldron 1999). Waldron laments that contemporary philosophers are contributing mainly to existing disagreements concerning justice, of which there are many, instead of pondering their significance: "it is rare to find a philosopher attempting to come to terms with disagreements about justice within the framework of his own political theory" (Waldron 1999, p. 1f.).

For Hampshire, all "modern societies are, to a greater or lesser degree, morally mixed, with rival conceptions of justice, conservative and radical, flaring into open conflict and needing arbitration" (Hampshire 1999, p. 38). These kinds of conflicts about "substantial justice" cannot be overcome but are not a defect. Harmony and consensus are, according to Hampshire, unrealistic goals. The best we can hope for are institutions and procedures that realize "procedural justice” and a fair "adjudication of conflicts” (Hampshire 1999, pp. 29, 45). Procedural justice is usually "imperfect and not ideal”, leading to compromise and not to consensus (Hampshire 1999, pp. 39, 42-43). Hampshire requires from all "moral enemies" to follow the principle "that contrary views of what is

ical justice usually depart from "practical" social and political issues and attempt to think through such issues "theoretically" or defend a specific conception of justice. However, it is not only philosophers, but also "ordinary" citizens, who have a sense of justice and conceptions of social and political justice that motivate their political actions. Sometimes citizen's conceptions of justice are informed by philosophical theory and theorists usually hope to influence "practical politics".

4 For a critical account of Herwig's view see Steinvorth in this volume.

5 One of the political theorists with whom Warnke substantiates her supposition of a hermeneutic turn is Michael Walzer and his claim that all social goods should be distributed according to their "social meanings" or citizen's "common understanding” of these goods (Walzer 1983, pp. XIV, 8-12, 312f.). From Warnke's perspective, there is disagreement on justice because meanings of social goods must be understood or interpreted and there are many different and justifiable ways to do this. 
just and fair are allowed equal hearing, equal access, in the city or state, and that no one conception of substantial justice in society is imposed by domination and by the threat of force" (Hampshire 1999, pp. 46, 29-46). ${ }^{6}$

In section $2(2.1-2.3)$ this article lays out several of the insurmountable disagreements on just distributions and a just society. This section will demonstrate that from the ancient world to the present day two fundamentally opposed basic conceptions of social and political justice can be traced in Western political thought. In modern terminology, these two irreconcilable conceptions can be characterized as egalitarian and non-egalitarian notions of social and political justice. While champions of egalitarian justice negate the natural and social inequalities of people and hold that it is just to establish arithmetic, numeric or simple equality, non-egalitarians or proportionalists like Plato, Aristotle or Nietzsche conceive of a just distribution of goods as proportional to existing inequalities. For non-egalitarians or champions of proportional justice, it is just to allot equal shares only to equals, not to everyone. The historical sketches in section 2 allow for a more detailed comprehension of the various aspects of the irreconcilable pluralism and conflict within conceptions of justice. Based on this understanding, section 3 sketches five possible reasons for deep disagreements among notions of social and political justice. This is intended as a first and preliminary step towards a better understanding of deep disagreements on justice. Section 4 briefly discusses the meta-ethical relevance of these irreconcilable disagreements. The section argues that statements about a just distribution or a just society do not refer to objective moral facts like ethical realists hold and cannot claim objective moral truth like cognitivists assert. As a consequence of the irreconcilable pluralism and conflict within conceptions of justice, we have to adopt a form of ethical relativism or skepticism that could be called "ethico-political relativism" or "ethico-political skepticism".

6 For Hampshire's case for procedural justice see Giorgini in this volume. 


\section{From ancient to contemporary philosophy: The irreconcilable pluralism and conflict of conceptions of social and political justice}

\subsection{Egalitarian versus proportional justice in Plato and Aristotle}

Plato's and Aristotle's writings contain valuable insights regarding opposing conceptions of distributive justice and the corresponding political systems that can be derived from them. The views of these ancient philosophers on political justice have played a vital role in shaping Western political thought. Their influence can still be traced in the irreconcilable conceptions of social and political justice found in contemporary philosophy. Going back to the Pythagoreans, in the Gorgias and the Laws Plato distinguishes between two concepts of equality. One kind of equality he calls equality of "measures, weights and numbers", the other one the "most genuine" and "best" equality (Leg. VI 757b; Plato 1997, p. 1433). Both forms of equality are inextricably linked to distributive justice, which Plato understands as political justice. Since Aristotle, the first form of equality is called "arithmetic" or "numeric" equality. In modern democracies this form of equality is realized and manifested in the principle "one citizen, one vote". Michael Walzer calls this form of equality "simple equality". 7 For Plato, legislators implement this form of equality when they "distribute equal awards by lot” (Leg. VI 757b; Plato 1997, p. 1433; cf. Leg. III 690c). This was the way in which most political offices were distributed in ancient democracies. As an aristocratic political thinker who defends the rule of the morally and intellectually best men, Plato rejects the democratic and egalitarian claim that a distribution of political power should allot equal shares to all male citizens (cf. Knoll 2017a).

The second form of equality is distinguished by Plato as a divine form of equality (Leg. VI 757b). In the Gorgias, Plato calls this form of equality "geometrical equality" (508a, cf. 490b-e). Geometrical equality is proportional equality. In order to politically apply it one needs

to grant much to the great and less to the less great, adjusting what you give to take account of the real nature of each - specifically, to confer high recognition on great virtue, but when

7 "Simple equality is a simple distributive condition, so that if I have fourteen hats and you have fourteen hats, we are equal” (Walzer 1983, p. 18). 
you come to the poorly educated in this respect, to treat them as they deserve. We maintain, in fact, that statesmanship consists of essentially this - strict justice (Leg. VI 757c; Plato 1997, p. 1433).

In this crucial and condensed passage Plato presents his theory of proportional justice, which is a political theory of distributive justice. It contains most of the building blocks of Aristotle's theory of distributive justice and in particular of the conception of political justice he prefers, which is an aristocratic conception focusing on political virtue (cf. Knoll 2010; Knoll 2017b). As the context of the passage elucidates, by addressing the distribution of recognition Plato a fortiori addresses the distribution of political offices and power. For him, such distribution should proceed according to proportional equality. Before political power is distributed, citizens need to be distinguished according to the criteria "virtue" (arête) and "education" (paideia) (cf. Aristotle: Pol. III 13, 1283a25; all trans. from Pol. and EN are M.K.s). The passage elucidates that Plato holds citizens to be quite unequal in these two respects. Political power should be allotted in proportion to the unequal amount of virtue and education citizens actually have. This is in line with his earlier mention of seven opposing "claims" (axiômata) used to justify ruling. There Plato pronounces that the "most important claim" is the one according to which "the ignorant man should follow the leadership of the wise and obey his orders” (Leg. III 690d; Plato 1997, p. 1379). Plato's distributive principle for political offices is "To each in proportion to his virtue and education”. This principle implies that it is just to allot equal shares only to equally virtuous and educated citizens, not to everyone.

Plato's theory of political justice is embodied in the "political system" (politeia) he outlines in the Laws. Despite his clear preference for proportional or geometrical justice, he argues for a mixture of the two forms of equality and a mixed constitution. However, like the political system Plato outlined in the Republic, the one of the Laws has a strong aristocratic character that makes sure that all important political offices are distributed to the morally and intellectually best citizens (cf. Knoll 2017a). Plato's mixed constitution includes the equality of "measures, weights and numbers" only for reasons of the stability of the political community. About the mixture of the two forms of equality, he declares, "So though force of circumstances compels us to employ both sorts of equality, we should employ the second [...] as little as possible” (Leg. VI 757e; Plato 1997, p. 1433). Plato's political concession to the champions of democracy does not mean, however, that egalitarian justice is in general logically consistent with proportional justice. Egalitarianism and proportionalism manifest not only opposing but irreconcilable moral convictions about political justice. Before substantiating this thesis, it seems natural to include Aristotle's political theory of 
distributive justice in the discussion, because Aristotle further develops and clarifies Plato's theory of two forms of equality and justice.

Aristotle's political theory of merit has already been extensively treated in the introduction to this volume. Therefore, here it suffices to focus on his report and analysis of disagreements on political justice and political systems. In the Nicomachean Ethics, Aristotle identifies a just distribution of political power with a distribution "according to merit" (kat' axian) (EN V 6, 1131a24-26). However, citizens with different political convictions substantially disagree with each other on how to measure merit. The democrats favor "freedom" as the appropriate criterion of merit, the supporters of oligarchy "wealth", the aristocrats "virtue" (arête), and an unnamed fourth group "noble birth" (EN V 6, 1131a27-29). In the Nicomachean Ethics, like later in the Politics, Aristotle distinguishes between four different conceptions of distributive justice: the democratic, the oligarchic and the aristocratic conception, and an undesignated fourth conception. Each of these conceptions is linked with its corresponding political system and justifies its specific distribution of political power. To argue that every free-born male citizen should get an equal share in political power is identical with the defense of democracy. To advocate the distribution of political offices in proportion to wealth is the same as to support oligarchy. To argue that political power should be given only to virtuous citizens is identical with the defense of aristocracy. ${ }^{8}$ Aristotle shares Plato's aristocratic political preferences. The best political system he outlines in Books VII and VIII of the Politics is a true aristocracy and embodies the aristocratic conception of political justice (cf. Knoll 2016, pp. 87-94). For Aristotle, the political dispute over the appropriate criterion of merit and the appropriate conception of distributive justice is, in the end, a quarrel over the appropriate political system.

This result of Aristotle's analysis is not only theoretically relevant. Rather, the close link between disagreements on political justice and disagreements on political systems elucidates the huge practical and political significance of his analysis. The reason for this is that such kinds of disagreements can lead to seditions, revolutions and civil wars. Therefore, it is not surprising that "upheaval" or "revolution" (stasis) is the topic of Book V of the Politics. In Book V, Aristotle argues that the general motive for sedition or political revolution is that citizens are outraged and get angry when they perceive the distribution of polit-

8 The "distribution of honors according to virtue (kat' aretên) seems to be the most characteristic trait of aristocracy; for virtue is the defining criterion of aristocracy, as wealth is the criterion for oligarchy, and free birth of democracy" (Pol. IV 8, 1294a9-11). For a reconstruction of the different arguments of the supporters of the four different conceptions of distributive justice see the introduction to this volume. 
ical power to be unjust, and therefore want to change the political system of their polis or state. ${ }^{9}$ For Aristotle, the disagreements between, say, supporters of an oligarchic conception of justice and oligarchy and champions of a democratic conception and democracy are a form of deep disagreements. It is not possible to convince either group through the use of reasons and arguments. This is also demonstrated by the many bloody upheavals and civil wars that happened after and during the horrific Peloponnesian War, in which Athens endorsed the democratic and Sparta the anti-democratic or oligarchic forces (cf. Thukydides III 82; Gehrke 1985). If Aristotle's analysis of deep disagreements on political justice and their inextricable link to deep disagreements on political systems is correct, he developed a political theory that does not only allow us to better understand several of the political revolutions that happened throughout history but also several of the political conflicts that keep happening in contemporary political systems.

In the Nicomachean Ethics, Aristotle interprets a just distribution of political power in general as a distribution "according to merit". For him, the source of disagreements on political justice is not this principle but the four opposing interpretations of merit. In the Politics, however, he opposes "numeric" or "arithmetic" (gar arithmô) equality like Plato to equality "according to merit" (kat' axian) (V 1, 1301b29f.; VI 2, 1317b4; cf. Plato, Leg., VI 751d). ${ }^{10}$ This opposition equals to the fundamental antagonism between arithmetic and proportional equality and justice. Proportional justice, which applies proportional equality, and egalitarian justice, which implements arithmetic equality, are not only opposites but are in general logically irreconcilable. They mutually exclude each other and represent two competing and contradictory understandings of justice that are connected to different sets of rules. This means that they cannot both be applied to solve the same distribution problem without nullifying each other (cf. Herwig 1984, pp. 97-99). Either justice is equality only for equals or (in an exclusive sense) for all (equals and unequals). The formal principle of proportional justice determines that only equals should get equal shares, while unequals should be allotted unequal shares. This formal principle is only in one case rec-

9 Ronald Polansky points out: "Since the disposition fostering change or sedition is ultimately the sense of injustice in distribution in the community, this must be the most general of all the causes operative in change" (Polansky 1991, p. 335). The main anthropological basis of Aristotle's theory of political revolutions is the human sense of justice (Pol. I 2, 1253a15-18; cf. Knoll 2016, p. 75 f.).

10 For Aristotle, "absolute justice" (haplos dikaion) is "according to merit" (Pol. V 1, 1301b35f.). For his preferences for an aristocratic conception of distributive justice and for a true aristocracy see the introduction to this volume and Knoll 2017b. 
oncilable with the formal principle of egalitarian justice that determines that all should get equal shares: in the case that everyone is equal. If in a distribution of political power there are unequal citizens like rich and poor ones, an oligarchic conception of proportional justice requires allotting unequal shares to them in proportion to their unequal wealth. For oligarchic justice, to distribute equal shares in such a case would be unjust. ${ }^{11}$ From the perspective of democratic justice, however, a distribution of unequal shares is unjust. Democratic justice, which is egalitarian justice, requires allotting equal shares to every citizen, which can be achieved through a universal and equal suffrage. Census suffrage, which is based on oligarchic justice, is unjust from the prevailing modern perspective of egalitarian justice. It is noteworthy that after the French Revolution, which had equality, liberty and fraternity written on its banner, still two out of three draft constitutions (1791 and 1795) excluded the poor male citizens from the right to vote for the National Assembly. For elections to the Prussian state parliament census suffrage, the three-class franchise, was reestablished after the revolution 1848/49 and stayed valid until 1918.

\subsection{The rise of egalitarian justice in modernity and the opposition of the champions of proportional justice}

The vast majority of French citizens in the $18^{\text {th }}$ century perceived the distribution of social goods and privileges in the ancient régime to be unjust. This was certainly one of the reasons for the French Revolution. This revolution was an important breakthrough for the rise of egalitarian justice. Since 1789, an increasing struggle for different forms of equality has become a central feature of modernity. According to an early egalitarian conception, social and political justice is achieved when everyone gets allotted equal rights. This idea goes back to the ancient conception of democratic justice, to some sophists, to the stoics, and to the Christian idea that all souls are equal in the eyes of God. ${ }^{12}$ In the ancient world,

11 If there were virtuous and non-virtuous citizens who had claims in the same distribution, to distribute equal shares would also be unjust from the perspective of an aristocratic conception of justice. Aristocratic justice requires allotting unequal shares to citizens in proportion to their unequal virtue. However, if the most virtuous citizens were poor, such a distribution would be unjust from the perspective of oligarchic justice.

12 In a remarkable passage, Friedrich Nietzsche, a fierce opponent of the rise of egalitarian justice, pronounces, "The poisonous doctrine 'equal rights for everyone' - Christianity disseminated this the most thoroughly". For Nietzsche, the French Revolution and other revolutions go back to the egalitarian "belief in the "privileges of the majority" and thus to "Christian value 
egalitarian justice primarily justified the claim for equal political participation of all male citizens. In the modern world, egalitarians call not only for an equal right to participate in the political life for all adult citizens but especially for equal civil and human rights. The egalitarian claim that everyone should have equal rights and liberties is also expressed by John Rawls's first principle of justice (Rawls 1971, p. 302).

Such egalitarian claims, however, have been opposed by several $19^{\text {th }}$-century philosophers. In his conception of social and political justice, Friedrich Nietzsche draws on the non-egalitarian or proportionalist views of Plato and Aristotle, claiming that a just distribution must allot goods in proportion to existing inequalities and allot equal shares only to equals, not to everyone:

The doctrine of equality! ... But no poison is more poisonous than this: because it seems as if justice itself is preaching here, while in fact it is the end of justice ... 'Equality for the equal, inequality for the unequal' - that is what justice would really say: along with its corollary, 'never make the unequal equal' (Twilight of the Idols, Skirmishes §48, Nietzsche 2005, p. $221 \mathrm{f}$.$) .$

Like Plato and Aristotle, Nietzsche is convinced that people are not only fundamentally unequal but also extremely different in worth and rank. Therefore they should not be allotted equal but unequal rights. Persons with higher value deserve prerogatives and privileges. This is the reason why Nietzsche often contemplates rank orders and the appropriate criteria for establishing them. Similar to how Plato and Aristotle conceive the close relationship between political justice and the polis, Nietzsche's conception of proportional justice is embodied in his notion of a well-ordered state or society (cf. Knoll 2017c). Concerning political justice, like Plato and Aristotle, John Stuart Mill defends proportionalism by advocating a distribution of unequal voting rights according to people's unequal "value" and "worth" of their opinions to be measured by their unequal virtue, intelligence and knowledge (2001, chap. 8, pp. 163, 169f.).

Before 1789, most of the favored positions in French society were distributed based on aristocratic privileges and thus on noble birth and inheritance. One slogan the revolutionaries used to oppose the ancient régime demanded "The career open to talents". The demand for equal opportunity ${ }^{13}$ was at least ideally a demand for equal chances for all talents. However, this claim for egalitarian justice

judgments these revolutions are translating into blood and crimes!” (The Anti-Christ §43; Nietzsche 2005, p. 40).

13 The demand that careers should be open to talents and that equal talents should have equal opportunities goes as far back as to the meritocracy Plato outlines in his Republic (cf. III, $415 b-c)$. 
was connected to claims and demands for proportional justice. The favored positions should not be distributed to all applicants but in proportion to individual merit or desert. An applicant deserves a position if he or she possesses certain qualities that allow us to anticipate "a future performance in which that quality is displayed" (Miller 2003, p. 137). This way of distributing the favored positions is the modern version of Plato's and Aristotle's claims that the political offices should be allotted "according to merit" (kat' axian). For Plato and Aristotle, the main reward for performing well in political offices was the "honor" or "recognition" (timê) the officeholders received from their fellow citizens (cf. Pol. III 10, 1281a31). In the modern world, the performance principle justifies high wages for talented and well-trained persons who perform well in their jobs. Such persons deserve not only a high wage but also recognition in proportion to their contributions to society. In distributing rewards, the performance principle applies proportional justice and gives to each according to his or her contribution. If two persons produce equivalent performances, then they deserve the same rewards. If a third person performs significantly better than those two, she deserves a higher reward in proportion to her better performance.

Connected to the rise of egalitarian justice, in the last years of the $18^{\text {th }}$ century a different and distinctively modern principle of distributive justice appeared on the political stage. It was either the radical egalitarian "Gracchus" Babeuf, the leader of a failed coup attempt against the Directory in 1796, or Johann Gottlieb Fichte who "first explicitly proclaimed that justice requires the state to redistribute goods to the poor" (Fleischacker 2004, pp. 76, 160f.). According to Babeuf, every man has received from nature "an equal right to enjoy all the goods" and the "aim of society is to defend this equality" (in Birchall 1997, p. 166; italics M.K.). In Western history, this was the "first definitive expression" of the "notion of distributive justice" in the modern sense (Fleischacker 2004, p. 55). The modern notion of distributive justice is inextricably linked to the welfare state and to the principle of a distribution of goods according to need (cf. the introduction to this volume). This latter principle, which is the distributive principle of the welfare state, can be applied in society jointly with the merit principle: "A society can give people what they deserve but also set resources aside to cater to needs" (Miller 2003, p. 155). This combination of principles is realized, at least to some extent or in imperfect form, in most modern welfare states.

Today, a society that distributes both rewards according to merit and some basic goods according to need is often welcomed as a just society (cf. Miller 2003, pp. 93, $200 \mathrm{f} ., 245)$. However, this contemporary conviction about social justice was firmly opposed by Karl Marx. In his 1875 Critique of the Gotha Program, Marx claims that in "a higher phase of communist society" labor duties and social wealth would be distributed by applying the principle "From each according 
to his ability, to each according to his needs!” (Marx 2009, p. 11). In the literature, it is a controversial issue as to whether Marx's principle has to be interpreted as his principle of distributive justice (cf. Geras 1989; Rawls 2007, pp. 335-372). For the purposes of this article it is not necessary to meddle in this debate and to embark on an extensive Marx-exegesis. It is enough to note that there are good reasons to understand Marx's principle as a principle of distributive justice. After introducing his principle and after expounding the considerations that lead him to postulate it, Marx declares that he now dealt enough with the issue of a “'fair distribution"” (gerechte Verteilung) (Marx 2009, p. 11). That Marx's principle is essentially a principle of distributive justice is also demonstrated by the fact that contemporary political philosophers treat the "needs principle"14 as such. In his theory of distribute justice, Michael Walzer defends the claim that basic social goods like security, health care or, more generally, welfare should be allotted in proportion to "socially recognized needs" (1983, pp. $25 \mathrm{f}$., 64-94). This principle is not an egalitarian principle because it aims at proportional equality and therefore allows for justified inequalities. Like Walzer, David Miller outlines a pluralistic theory of distributive justice that recognizes need, desert, and equality as principles and “criteria of social justice” (2003, pp. 41, 93, 245).

In his Critique of the Gotha Program, the draft program of the United Workers' Party of Germany, Marx distinguishes two phases of communist society. Despite the fact that in the earlier period social privileges and class differences are abolished, it is "still stamped with the birthmarks" of the capitalist society from which it emerges (2009, p. 8). In this socialist period every working individual receives - after indispensable deductions - back from society "means of consumption" exactly in proportion to her contribution measured by her "individual quantum of labor" (2009, p. 8f.). Like the exchange of commodities in capitalist society, it is an "exchange of equal values". For Marx, such a socialist organization of society has several inevitable "defects" and is "stigmatized by a bourgeois limitation” (2009, p. 8f.). If people are merely measured and rewarded by the "equal standard" of their labor contribution to society, they will receive unequal shares of the social wealth. The reason for this is that "one man is superior to another physically, or mentally, and supplies more labor in the same time, or can labor for a longer time". The performance principle "tacitly recognizes unequal individual endowment, and thus productive capacity, as a natural privi-

14 Norman Geras designates Marx's whole principle "From each according to his ability, to each according to his needs!" as the "needs principle” (1989, p. 221). However, it is more appropriate to apply this designation only to the second part of Marx's principle: "To each according to his needs!" 
lege" (2009, p. 9f.). There is another reason why Marx rejects the performance principle. A distribution of social wealth in proportion to labor contributions leads to further inequalities because unequal individuals - "one worker is married, another is not; one has more children than another, and so on and so forth" - have unequal needs. This means that a worker who is a bachelor with no family will be significantly wealthier than a worker who has large needs due to the large family she is responsible for (2009, p. 10).

These are the considerations that lead Marx to postulate the principle "From each according to his ability, to each according to his needs!" that should regulate distributions in the final phase of communist society. This principle uncouples - and this is its crucial point - what individual citizens contribute to society with their labor and their natural endowments from the distributive claims they have to the sum-total of the fruits of society's labor. For Marx, the distribution of social wealth should be independent from unequal labor contributions and should be exclusively based on unequal individual needs. It seems likely that Babeuf's egalitarian convictions that every man has an equal right to all the goods and that society has to aim at this equality is the base for Marx's principle (Birchall 1997, pp. 95f., 166). This principle could mean that in "a higher phase of communist society" in which "all the springs of co-operative wealth flow more abundantly" a relatively unproductive worker who has large needs due to her large family receives significantly more means of consumption from society than a relatively productive worker who is a bachelor with no family (Marx 2009, p. 11).

From the perspective of the performance or merit principle, however, it is extremely unjust if those persons who contribute more to society receive significantly less than those who contribute less. However, Marx does not acknowledge or approve the "bourgeois" performance principle at all. His own distributive principle is not only irreconcilable with the performance principle but nullifies it or, in the case just mentioned, even allows it to be reversed. For Marx, the distribution of social wealth should be exclusively based on unequal needs. Between the advocates of the performance or merit principle and Marx exists a deep disagreement on social justice.

An important modern witness to the irreconcilability of conceptions of social and political justice is the sociologist and philosopher Max Weber. Weber's view on justice is part of his general view that modernity is characterized by an irresolvable pluralism and struggle of values. Views similar to Weber's were pronounced by Isaiah Berlin who holds that the "normal human situation" is that "ends equally ultimate, equally sacred" and "entire systems of value" "come into collision without possibility of rational arbitration” (Berlin 2013, p. 94; cf. 
pp. 94-99). ${ }^{15}$ For Weber, a distinctive trait of the modern world is the existence not only of irreconcilable conceptions of the good but of justice. ${ }^{16}$ Facing such a situation, each individual has to make a personal decision about which of the competing values she wants to choose and cherish. Weber persuasively states about social justice that,

The implications of the postulate of "justice" cannot be decided unambiguously by any ethic. Whether one, for example - as would correspond most closely with the views expressed by Schmoller - owes much to those who achieve much or whether one should demand much from those who accomplish much; whether one should, e.g., in the name of justice [...] accord great opportunities to those with eminent talents or whether on the contrary (like Babeuf) one should attempt to equalize the injustice of the unequal distribution of mental capacities through the rigorous provision that talented persons, whose talent gives them prestige, must not utilize their better opportunities for their own benefit these questions cannot be definitely answered. The ethical problem in most social-political issues is, however, of this type (Weber 1949, p. 15f.).

According to Weber, there is no possibility for a rational solution to deep disagreements on social and political justice. Though moral philosophers can give arguments for their conceptions of justice, they cannot deliver an ultimate and undisputable rational grounding for any of their different normative theories. For the conflict between opposing values and ends there exists "no (rational or empirical) scientific procedure of any kind whatsoever which can provide us with a decision” (Weber 1949, p. 19; cf. Gölz 1978).

\subsection{Contemporary disagreements between supporters of egalitarian and proportional justice}

In today's world, the performance principle and meritocracy are still advocated by political philosophers (cf. Miller 2003, pp. 177-202). However, most contemporary political theorists are endorsing egalitarian justice. In the tradition of Babeuf and Marx, contemporary egalitarians like Ronald Dworkin and Richard Arneson claim that a just society has to establish some form of arithmetic or numeric equality like "equality of resources" or "equality of opportunity for welfare" (cf. Cohen 1989). The goal of egalitarian justice is - if this is compatible

15 For a critique of Berlin's value pluralism see Steinvorth in this volume.

16 From Weber's perspective, Rawls's move to come to terms with the opposing conceptions of the good by striving for a consensus on a political conception of justice and a just social framework that allows these conception to coexist does not work. 
with upholding other values like liberty - to make people more equal in these respects. Following Dworkin's suggestion "that the idea that each person matters equally is at the heart of all plausible political theories”, Will Kymlicka pronounces that "each theory shares the same 'egalitarian plateau'” (Kymlicka 2002, p. 4; cf. Haus in this volume). However, there are still contemporary political philosophers like John Kekes who publish serious treatises like The Illusions of Egalitarianism (2003), which argue Against Liberalism (1997). Going back to Aristotle, Kekes claims "that the worth of human beings varies with their moral merit" and that "justice makes the right" to resources "contingent on what their recipients deserve” (1997, p. 120). Kekes defends proportional justice and deeply disagrees with the liberal and egalitarian conception of justice. Other philosophers such as Harry Frankfurt argue that equality is morally irrelevant and propose that we should rather focus on non-relational standards like distributing a sufficient amount of goods to everyone (Frankfurt 1988, 2015; cf. Krebs 2000).

John Rawls, whose defense of the welfare state has already been treated at length in the introduction to this volume, starts off his theory of distributive justice from a "substantive egalitarian principle of justice which assumes that all departures from equality have to be morally justified” (Barry 1995, p. 153). In some crucial aspects, Rawls's position on social justice comes close to Babeuf's and Marx's views. Like Marx, he opposes recognizing "unequal individual endowment, and thus productive capacity, as a natural privilege" (Marx 2009, p. 10). Considering this closeness and Rawls's extensive studies of Marx's view on justice, it could even be argued that he appropriates Marx's view and elaborates it (Rawls 2007, pp. 335-372). ${ }^{17}$ As a champion of egalitarian justice, Rawls negates the natural and social inequalities of people. For him, no one "deserves his greater natural capacity nor merits a more favorable starting place in society". Rawls's intuition about social justice is, “Those who have been favored by nature, whoever they are, may gain from their good fortune only on terms that improve the situation of those who have lost out” (1971, §17, p. 101f.). Based on this central intuition, from which he develops his difference principle, Rawls advocates a strong welfare state that redistributes income and wealth from the well-off members of society to the least advantaged ones (cf. Knoll 2013). As already expounded in the introduction to this volume, Rawls rejects a distribution of primary goods like income and wealth according to merit and advocates, like Marx, a distribution according to need. However, if it comes to wages, Rawls allows, in contrast to Marx, inequalities based on efforts and contributions in

17 For the claim of a deep disagreement between Marx's principle of distributive justice and Rawls's difference principle see Demir in this volume. 
order to create incentives to work more or more efficiently (1971, §§ 43, $47 \mathrm{f}$., pp. 276 f., 304 f., 309, 312). Rawls's egalitarian goal is, nevertheless, to make people more equal concerning certain primary goods like rights, liberties, opportunities, income, wealth and self-respect.

An opposing conception of social justice and of a just political order has been introduced by the libertarian Robert Nozick. For his political thought, like for Rawls's, individual rights are central. However, he strongly disagrees with the (im-)moral core of Rawls's view. According to Nozick, even if people might not deserve their natural endowments, they still rightfully own them and have a justified claim to them (1974, p. 225). Therefore, he strongly disagrees with Rawls's conception of social justice that regards people's "natural talents as a common asset" and "treats people's abilities and talents as resources for others” (1974, p. 228; cf. pp. 30, 33, 172; cf. Rawls 1971, p. 101). Rawls’s view equals to introducing "a head tax on assets and abilities” (1974, p. 229). For Nozick, a just society is not allowed to redistribute resources from the rich to the poor as this violates people's rights. Nozick himself develops an "entitlement theory of justice" that goes back to Locke and the reductionist early modern view that distributive justice concerns mainly the just appropriation and just transfer of property (1974, pp. 153, 149-182; cf. Kersting 2000, pp. 47-53). In a well-known polemic statement, Nozick, the advocate of a minimal state, objects to Rawls's ideal of an extensive welfare state and to the redistributions it requires: "Taxation of earnings from labor is on a par with forced labor. Some persons find this claim obviously true: taking the earnings of $n$ hours labor is like taking $n$ hours from the person; it is like forcing the person to work $n$ hours for another's purpose" (1974, p. 169).

The deep disagreements between Rawls's and Nozick's views on social justice could be interpreted as a resumption of the deep disagreements between advocates of the performance or merit principle and Marx's views on social justice. While Nozick argues for a version of "political individualism" and the performance principle, Rawls defends "political communalism" and a distribution of goods that should be primarily based on the needs of the least advantaged citizens. ${ }^{18}$ As a non-egalitarian, Nozick has no problem with social inequality and defends an unequal distribution of wealth and income in proportion to labor contributions based on unequal natural endowments and efforts. On the contrary, Rawls aims at socially compensating for the natural and social inequalities

18 In his contribution to this volume, Ulrich Steinvorth argues for the thesis that we can rationally arbitrate between Rawls's and Nozick's conceptions of justice. Steinvorth characterizes Rawls's view as "political communalism". For good reasons he prefers this term to "political communism". 
and at establishing the highest possible level of social equality. However, while Marx calls for a distribution of social wealth independent from labor contributions, Rawls concedes some unequal rewards and wages based on efforts and contributions.

\section{Reasons for deep disagreements among notions of social and political justice}

The preceding analysis of the history of political thought on distributive justice demonstrates that deep disagreements among notions of social and political justice are one of its characteristic features. From antiquity to the present day we can observe disagreements on values, just distributions and a just society that cannot be resolved through the use of reasons and arguments. Perhaps the only progress in this history is the emergence of the modern notion of distributive justice that is connected to the welfare state and a distribution of basic goods according to need (cf. Fleischacker 2004). However, the conflict between egalitarian and non-egalitarian or proportional justice cannot be resolved by attributing the conflicting views to different historical periods and by claiming a "moral progress" towards egalitarianism (cf. Herwig 1984). ${ }^{19}$ As the preceding analysis demonstrates, the fundamentally opposed two basic conceptions of social and political justice can be traced both in antiquity and in modernity.

There are good reasons to suppose with Aristotle and Rawls that all human beings possess a "sense of justice” (Pol. I 2, 1253a14-18; Rawls 1971, §4, § 39, $\S 77$; pp. 19, 243, 505). Small children somehow notice when they or others are treated unjustly. However, as adults opposing intuitions of what constitutes a just distribution and a just political order are formed. As a first and preliminary step toward a better understanding of such disagreements, this section sketches five possible reasons that can explain them. This sketch and the exact relationship between these reasons have to be elaborated through detailed analyses in future research.

(1) For Hampshire, moral conflict is inevitable because human imagination, which makes us unique individuals, causes us to develop not only different notions of a good and happy life but different moral outlooks (1983; 1999, pp. 18, 30, 68; cf. Giorgini in this volume).

19 For arguments against a Hegelian historical or evolutionary solution of disagreements see Ribeiro 2011, pp. 18-21. 
(2) In Spheres of Justice, Walzer bases his theory of justice on the meanings of social goods in particular societies (1983). From this perspective, disagreement can be explained by the fact that several different interpretations of these meanings are possible and justifiable (Warnke 1993). ${ }^{20}$

(3) A classical approach to explaining disagreements on justice can be found in the Marxist tradition. From this perspective, justice is based on class interest. Philosophical disagreements regarding just distributions and just political orders can be understood by tracing them back to the social or economic position of the theoretician. For Marx, the "economic structure of society" is "the real foundation" "on which arises a legal and political superstructure and to which correspond definite forms of social consciousness". It is human's "social existence that determines their consciousness" (1987, p. 263). According to Marx's view, a conception of justice generalizes a particular social position or expresses the particular interest of one social class. The position of the less favored social classes suggests an egalitarian view according to which it is just to establish a good deal of social equality and to redistribute the income of the privileged classes. On the contrary, the social position and interest of the privileged classes prompt a non-egalitarian view that conceives of a just distribution of social goods as one in proportion to existing inequalities. This approach to explaining the disagreements on social and political justice assumes that moral judgments on justice are not an independent phenomenon but can be reduced to objective interests that go along with different social positions. An argument for this approach is that it takes into account human egoism. Rawls had good reasons to situate the parties who decide on principles of justice "behind a veil of ignorance” (1971, § 24, p. 136). Such an information deficit about one’s own social position and natural endowments prevents people from making choices in their personal interest and is intended to lead to impartial decisions. However, it can be shown empirically - consider Marx, Engels and most members of the Frankfurt School - that not all theoreticians advocate their "objective class interests".

(4) A fourth approach to explaining disagreements on justice could be called a cognitive approach. This approach can be illustrated by an important change in Rawls's view. In A Theory of Justice, Rawls defends a Kantian understanding of reason as a general or universal faculty. For him, the parties who decide about principles of justice in the initial situation of equality are "similar rational and similarly situated", and therefore "each is convinced by the same arguments" (1971, § 25, p. 139). On the contrary, in Political Liberalism, Rawls concedes "dif-

20 Cf. footnote 5 of this article. 
ficulties in arriving at agreement in judgment" or the reality of "reasonable disagreement" which is "disagreement between reasonable persons" (2005, II § 2, pp. 55, 58). Now Rawls acknowledges as a "general fact" of "the political culture of a democratic society" that "many of our most important judgments are made under conditions where it is not expected that conscientious persons with full powers of reason, even after free discussion, will all arrive at the same conclusion” (2005, I § 6, p. 36; II § 2, p. 58). Rawls denotes the causes or sources of reasonable disagreements as "the burdens of judgment"21 and presents an open list: Evidence is difficult to evaluate, the overall weight of the manifold relevant (normative) considerations on both sides of an issue is hard to assess, our concepts are vague and therefore we must rely on interpretations and judgments about interpretations, our moral and political judgments are shaped by our disparate life experiences, it is difficult to select among our moral and political values and to prioritize them (2005, II § 2, pp. 55-57). Generally speaking, "Different conceptions of the world can reasonably be elaborated from different standpoints and diversity arises in part from our distinct perspectives” (2005, II $\S 2$, p. 58). With his burdens-of-judgment argument Rawls wants to explain the modern pluralism of "reasonable comprehensive religious, philosophical, and moral doctrines” (2005, I § 6, p. 36; II § 3, pp. 54f., 60). ${ }^{22}$ There is evidence for "attributing to Rawls the belief that issues of justice are not subject to the burdens of judgment" (Waldron 1999, p. 152). However, this exemption cannot be justified. The burdens of judgment can also be "used to characterize our political deliberations, including our deliberations about rights and justice, as well as ethics, religion, etc." (Waldron 1999, p. 112). The burdens of judgment can partly explain our deep disagreements on social and political justice. By admitting "reasonable disagreements", Rawls unintentionally undermines his ideas of an overlapping consensus on a political conception of justice and of a possible agreement on principles of social justice (cf. Waldron 1999, p. 151f.; for a realist notion of reasonableness see Wolthuis in this volume).

The cognitive approach to explaining the causes of disagreements on justice can and should, of course, be pursued beyond Rawls's discussion of the burdens of justice. This approach points toward a broader investigation of human reason.

21 For the burdens of judgment see also Peter Caven's and Michal Rupniewski's contributions to this volume.

22 "The evident consequence of the burdens of judgment is that reasonable persons do not all affirm the same comprehensive doctrine” (2005, II §3, p. 60). Rawls also declares, "These burdens of judgment are of first significance for a democratic idea of tolerance” (2005, II § 2, p. 58; cf. Introduction, p. XXIVf.). An understanding of the sources or causes of the modern pluralism of comprehensive doctrines should make it easier to tolerate the doctrines one disapproves. 
Why do philosophers constantly disagree with each other? Why are they only rarely convinced by each other's arguments? Considering that "philosophy is the business of disagreement", it is "very surprising" that until today philosophy has not "worked out a fairly sophisticated account of disagreement" (Ribeiro 2011, p. 3). In the terminology of Jean-François Lyotard's The Differend, there exists a conflict or "differend" (différend) between egalitarian and non-egalitarian conceptions of social and political justice (1988). For Lyotard, like other conflicts, this one cannot be decided because there is no rule for a judgment that can be applied to both conceptions. Highly relevant for future research on the cognitive causes for disagreements are also the contemporary debates on deep and peer disagreements (Fogelin 2005, Siegel 2013).

(5) A fifth approach to explaining disagreements on conceptions of justice focuses on the opposing images of humanity connected to them. According to this approach, disagreements on justice can be explained by a clash of the underlying conceptions of man. In the language of Fogelin's Logic of Deep Disagreements, the conflicting convictions that humans are either equal or (in an exclusive sense) unequal, or rather that either the one or the other matters, are the "underlying principles" or "framework propositions" that can surface as the reasons that create the disagreements on justice (2005, p. 8). ${ }^{23}$ For non-egalitarians like Plato, Aristotle, and Nietzsche, human beings are fundamentally unequal and have unequal value. On the contrary, for egalitarians all human beings have equal worth, and are therefore equally worthy of concern and respect. For Plato, people can be as different as reason, the highest part of the soul, and the appetites, the lowest part of the soul. For Aristotle, person's different human value corresponds to the degree in which they have perfected their ethical virtues, their character, and their practical and theoretical reason. Based on people's different worth and rank, for Plato, Aristotle, and Nietzsche it is just to distribute equal shares only to equals, not to everyone. On the contrary, based on their conviction of human equality, egalitarians aim at establishing more equal-

23 One of Fogelin's examples for deep disagreements is the abortion debate: "Parties on opposite sides of the debate can agree on a wide range of biological facts" and also "on the sanctity of human life" (2005, p. 8). However, "the central issue of the abortion debate is the moral status of the fetus", and in regard to this issue the one party believes that at conception or shortly afterwards "an immortal soul enters into the fertilized egg" and the other party does not. There is no way of solving such a disagreement through the use of reasons and arguments because of the irreconcilable belief systems that the disagreement is based on (2005, p. 8f.). For a critique of Fogelin's "Wittgensteinian view" of the "limits of reason" see Siegel 2013, pp. 16-21; cf. Ribeiro 2011, pp. 7-9. 
ity among persons. ${ }^{24}$ For non-egalitarians, just distributions should correspond to natural inequalities, for modern egalitarians they should move beyond such inequalities towards more equality (cf. Herwig 1984, p. 202). If deep disagreements on just distributions and just political orders can be explained primarily through disagreements about the equality or inequality of human beings, future research has to examine the reasons for deep disagreements about human nature.

\section{The meta-ethical relevance of deep disagreements among notions of social and political justice}

The linguistic turn in the philosophy of the $20^{\text {th }}$ century lead to a new branch of moral philosophy called meta-ethics. This new discipline does not defend any normative principles or ethical theories but investigates the nature of morality and the meaning of moral statements and judgments. What do we mean when we claim that something is right, good or just? Are we referring to moral facts and moral truth or do we just express our personal, or our society's, feelings, thoughts, and attitudes? Meta-ethics analyzes more than just moral language and arguments; it also analyses the ontological and epistemological questions connected to them. "Ethical realists" claim that moral statements and judgments refer to moral facts or an objective moral reality, anti-realists (called moral skeptics, ethical relativists or ethical subjectivists) deny this. "Cognitivists" maintain that moral judgments can be true or false and that there is such a thing as moral knowledge. "Non-cognitivists" reject the idea that moral knowledge is possible.

The preceding demonstration that deep disagreements among notions of social and political justice are a characteristic feature of the history of political thought is significant for meta-ethics. The reason for this is that the existence of such deep disagreements is a strong argument against ethical realism and cognitivism. More than two thousand years of intense philosophical research on justice - our central moral, social and political virtue - has neither uncovered objective truth about the matter nor led to any agreement among scholars. Looking at it the other way round, deep disagreements among notions of social and political justice exist because there are no objective moral reality and no moral

24 Cf. Sommer 2016, pp. 42f., 66f. For a more detailed account of the opposing images of humanity see the introduction to this volume. 
facts. There is nothing in the world to back up one of the conflicting philosophical views on justice and no procedure using moral facts to solve moral disagreements and to show that one view is wrong and one is right. If the argument against moral realism from deep disagreements is persuasive, we attain a sixth reason for explaining deep disagreements among notions of social and political justice. The philosophical argument that the existence of deep disagreements on justice refutes ethical realism is similar to the well-known sociological argument from relativity, which it complements.

Let's start with some preliminary meta-ethical observations and considerations. If we analyse ordinary moral language and thought, we notice that it usually contains claims about objective moral facts. We frequently exclaim, "This is not just!" However, the fact that our moral statements and judgments make such claims does not prove that moral facts or objective values exist. As John L. Mackie put it: "The claim to objectivity, however ingrained in our language and thought, is not self-validating" (1977, p. 35). Despite their claims to objectivity, our moral statements and judgments could still just express our subjective moral feelings, thoughts, desires, and attitudes. As Mackie argues, the "supposed objectivity of moral qualities" could arise from "the projection or objectification of moral attitudes” (1977, p. 42). Just as we tend to read our feelings into the objects, for example by ascribing a fungus that disgusts us the quality of foulness, we project our subjective moral feelings, desires, and attitudes into the world (1977, p. 42). Furthermore, invoking an objective moral reality could simply have the strategic function to make our subjective judgments appear stronger and more authoritative. Consider children who say that they really need something, which just expresses that they really want it. For Mackie, moral claims pointing to something "objectively descriptive" are "all false" (1977, p. 35). Mackie supports this "error theory" mainly with "the argument from relativity and the argument from queerness" and claims that the latter is more important than the former (1977, pp. 35-42).

The philosophical argument from queerness has an ontological part: "If there were objective values, then they would be entities or qualities or relations of a very strange sort, utterly different from anything else in the universe" (1977, p. 38). Examples for such queer entities are Plato's forms and in particular his form of the good. Plato was an ethical realist and cognitivist. The argument from queerness also has an epistemological part. If objective moral facts existed, it would be very difficult to explain how we could access them: "Correspondingly, if we were aware of them, it would have to be by some special faculty of moral perception or intuition, utterly different from our ordinary ways of knowing everything else” (1977, p. 38). In a recent counter to the argument from queerness, Julian Nida-Rümelin defends an ethical realism that is ontologically agnostic 
(2016, pp. 91-136). However, this does not leverage out the argument. The ethical realist who both claims that moral facts exist and that we can somehow access them has the burden of proof. If we are to accept the belief that objective values are part of the structure of the world, we should be able to track or comprehend their nature and their place in this world. ${ }^{25}$ Likewise, someone who claims an empirical fact, say, the existence of centaurs, should be able to prove their existence to the skeptic. If the moral skeptic needs to identify moral facts with an inaccessible metaphysical or divine reality like the one usually associated with Plato's form of the good, she has good reasons to doubt their existence.

The sociological argument from relativity goes back to the sophist Protagoras who was informed about the variation in customs and moral codes from one culture to another by the historian Herodotus. From this, Protagoras concluded that in moral matters there are no universal truths. However, for good reasons he argued that some moral beliefs are more beneficial than others (Plato: Theaetetus $166 \mathrm{e}-167 \mathrm{~d}, 172 \mathrm{a} / \mathrm{b}, 177 \mathrm{~d} / \mathrm{e}) .{ }^{26}$ Today, based on history, anthropology, ethnology, and sociology, descriptive morality informs us about the wide range of diversity in moral beliefs. This diversity and the existence of all kinds of moral disagreements - on values, a good life, the common good, politics, abortion, euthanasia, animal rights, and on and on - are the premises of the argument from relativity. ${ }^{27}$ This argument claims both that moral diversity and disagreement suggest "that there are no absolute universal moral standards binding on all men at all times" and that the validity of moral beliefs and principles depends on their cultural or even on their individual acceptance ${ }^{28}$ (Ladd 1985, pp. 1, 3). This argument against ethical realism "has some force simply because the actual variations in the moral

25 For Nida-Rümelin, it is an undeniable normative fact that murder is morally wrong (2016, pp. 124, 130). To be sure, this is a universally shared moral judgment or belief and there are universally shared reasons to think that murder is morally wrong. However, in order to substantiate the view that beyond these judgments, beliefs and reasons there exists such a thing as an objective moral fact to which they refer would require an additional proof.

26 Plato deeply disagreed with Protagoras's ethical relativism or skepticism. His own theory that the philosopher can achieve the truth about objective forms of justice and the good that exist separate from the sensual world is an attempt to refute Protagoras's view that in these matters there are no universal truths because justice and moral goodness varies from one culture to another. Plato's student Aristotle, however, deeply disagreed with Plato that such forms exist. 27 Moral disagreements are embedded in a wider set of religious and philosophical disagreements.

28 The position that the validity of moral beliefs and principles depends on their cultural acceptance is called "conventional ethical relativism". The more radical position is "subjective ethical relativism" that bases the validity of moral beliefs and principles on the "acceptance by an individual agent” (Pojman/Fieser 2012, p. 16). 
codes are more readily explained by the hypothesis that they reflect ways of life than by the hypothesis that they express perceptions, most of them seriously inadequate and badly distorted, of objective values" (Mackie 1977, p. 37). If moral truth exists, contradicting norms and values cannot be likewise true. The enormous amount of existing moral diversity and disagreement suggests that no moral view can be understood as the apprehension of the one objective moral truth (cf. Birnbacher 2003, p. 391f.; Waldron 1999, p. 177).

The argument against ethical realism from deep disagreements on justice is above all a philosophical argument. It is not just an argument concerning ethics but as well political philosophy. ${ }^{29}$ This argument is not primarily based on societies' or cultures' disagreements on moral codes or distributions in the political community but on disagreements among researchers and scholars. Even if we suppose that philosophers' judgments about a just distribution or just society are influenced by their own personal and cultural backgrounds, their disagreements supposedly go deeper and are more rational than "common" people's and societies' disagreements on values and moral codes. Philosopher's views are not only based on their "considered judgments" 30 on justice but on elaborated theories that they defend with carefully constructed arguments. According to an old-fashioned view, philosophy is committed to finding out the truth. However, after more than two thousand years of continuous philosophical disagreements on social and political justice, it is very likely that no objective truth about justice exists. Considering the enormous amount of past philosophical efforts, there is no reason for optimism that the lack of consensus could change in the future (cf. Ribeiro 2011, pp. 18-21).

Of course, the mere fact of continuous deep disagreements on justice does not conclusively rule out the possibility that an objective moral reality or moral truth exists. Hypothetically, supporters of proportional justice like Plato could have been able to perceive the truth and all egalitarians could have distorted or false views on justice or vice versa. However, the burden-of-proof argument also applies to these cases. Neither Plato nor other moral realists were able to demonstrate the existence of an objective moral reality. Similarly, as Waldron puts it, "moral disagreement remains a continuing difficulty for realism, even

29 For Aristotle, justice is a moral or ethical virtue that is also applied in arguments about political distributions (cf. Knoll 2016). Similarly, for Rawls and other contemporary philosophers, political philosophy is applied moral philosophy. There are good reasons for this view and for understanding justice claims as moral claims.

30 Rawls defines "considered judgments" as those "judgments in which our moral capacities are most likely to be displayed without distortion". They are "rendered under conditions favorable to the exercise of the sense of justice” (Rawls 1971, § 9, p. 47). 
it does not entail its falsity, so long as the realist fails to establish connections between the idea of objective truth and the existence of procedures for resolving disagreement" (1999, p. 177). In mainstream sciences, practitioners disagree with each other, say, about aspects of climate change, but there is some agreement on the methods and procedures how to settle or resolve such disagreements. However, "nothing remotely comparable" exists among moralists or moral philosophers (Waldron 1999, p. 178). Waldron's argument from the lack of consensus on how to solve moral disagreements is connected to the burden-of-proof argument. Both arguments are part of the philosophical argument against moral realism from deep disagreements. Combined with the arguments from queerness and from relativity, this results in a very strong case against moral realism and cognitivism. ${ }^{31}$

\section{Conclusion}

This article has demonstrated that deep disagreements among notions of social and political justice are a characteristic feature of the history of political thought. Despite the fact that today there is much more consensus on democracy than a hundred years ago, disagreements on political justice linger on (cf. Knoll/Şimşek in this volume). This article has also shown that the fact of deep disagreements on justice yields important arguments for the case of the moral skeptic or ethical relativist against the moral realist and cognitivist. Considering that deep disagreements among notions of social and political justice concern both ethics and political philosophy, it would be most appropriate to denote the position defended here as ethico-political relativism or ethico-political skepticism (for the relation of disagreements to relativism and skepticism see Ribeiro 2011, pp. 9-11).

This article has only sketched six reasons that explain deep disagreements among notions of social and political justice. Future research needs to elaborate on this sketch and analyze the exact relationship between these reasons. Equally important is the question of how to cope with deep disagreements on justice. Considering that such disagreements can lead to violent conflicts and civil wars, this task is of serious practical and political relevance. Conventional ethical relativists often claim that their theory supports the value of tolerance (cf.

31 Ronald Dworkin claims "that there is often a single right answer to complex questions of law and political morality" and rejects the "no-right-answer" thesis (1978, p. 279f.). However, the argument from deep disagreements on social and political justice demonstrates that Dworkin's view cannot be upheld. 
Pojman/Fieser 2012, p. 20 f.). However, deep disagreements on justice lead rather to enmity among the supporters of egalitarianism and proportionalism. The least we can ask for is that the opposed parties of such conflicts respect the fact that reasonable disagreements on justice exist. This means that they should not oversimplify the matter by degrading the opponent as ignorant, backward, prejudiced, unintelligent, and such like (cf. Waldron 1999, p. 111; Ribeiro 2011, pp. $7-11) .^{32}$

To be sure, many actual political conflicts are caused or can be derived from disagreements on social and political justice. This is especially true when firm moral and political convictions are involved as it is the case in quarrels between liberals and conservatives, generally speaking, between the political "left" and "right". Considering that justice is the most important moral, social, and political virtue, it is even possible to define these terms based on the corresponding egalitarian or non-egalitarian convictions about social and political justice. Similar ideas have been expressed by Noberto Bobbio in his small study Left and Right (1997). According to Bobbio, the political convictions of the "left" and "right" are not only connected to egalitarian or non-egalitarian views of justice, but to opposing images of humanity that go along with them (cf. section 3 of this article). The hypothesis that followers of German political parties on the left share egalitarian views and adherents of German political parties on the right non-egalitarian views, has been successfully verified applying empirical research (Fichtner 2012).

Disagreement has become a new research interest among scholars with different backgrounds. Deep disagreements exist not only among notions of social and political justice and among ethicists, but among philosophers in general (Ribeiro 2011). There are new controversies on deep and peer disagreements and a debate on the epistemology of disagreement (cf. Siegel 2013). Political scientists engage in conflict research and we certainly see a lot of political and moral disagreement in domestic politics and international relations. It would be desirable, if future research focused more on the various commonalities and connections of the different forms of disagreement.

32 According to Waldron, respecting disagreement "need not involve rejecting the premise about the singularity of truth; that is, it need not involve anything like relativism. Respect has to do with how we treat each other's beliefs about justice in circumstances where none of them is self-certifying, not how we treat the truth about justice itself" (1999, p. 111). 


\section{Bibliography}

Barry, Norman P. (1995): An Introduction to Modern Political Theory. Third revised and expanded edition. Houndsmills: Macmillan (first edition 1981).

Berlin, Isaiah (2013): “The Originality of Machiavelli” (first published 1972). In: Berlin, Isaiah: Against the Current. Essays in the History of Ideas. Henry Harvey (Ed.). Princeton, Oxford: Princeton University Press (second edition, first published 1979), pp. 33-100.

Birchall, Ian H (1997): The Spectre of Babeuf. Houndsmills, New York: Macmillan/St. Martin's Press.

Birnbacher, Dieter (2003): Analytische Einführung in die Ethik. Berlin, New York: De Gruyter. Bobbio, Noberto (1997): Left and Right. The Significance of a Political Distinction. Chicago: University of Chicago Press (first published 1993).

Cohen, Gerald A. (1989): “On the Currency of Egalitarian Justice”. In: Ethics 99, pp. $906-944$.

Dworkin, Ronald (1978): Taking Right Seriously. With a new appendix and a response to critics. Cambridge, MA: Harvard University Press.

Fichtner, Georg (2012): Die gerechtigkeitstheoretischen Grundlagen der politischen Begriffe "links" und "rechts". Munich: Grin.

Fleischacker, Samuel (2004): A Short History of Distributive Justice. Cambridge, MA: Harvard University Press.

Fogelin, Robert J. (2005): “The Logic of Deep Disagreements”. In: Informal Logic 25. No. 1, pp. 3-11 (first published 1985).

Frankfurt, Harry G. (1988): “Equality as a Moral Ideal”. In: Frankfurt, Harry G.: The Importance of What We Care about. Philosophical Essays. Cambridge: Cambridge University Press, pp. 134-158.

Frankfurt, Harry G. (2015): On Inequality. Princeton, Oxford: Princeton University Press.

Gehrke, Hans-Joachim (1985): Stasis. Untersuchungen zu den inneren Kriegen in den griechischen Staaten des 5. und 4. Jahrhunderts. Munich: Beck.

Geras, Norman (1989): “The Controversy about Marx and Justice”. In: Callinicos, Alex (Ed.): Marxist Theory. Oxford: Oxford University Press, pp. 211-267.

Gölz, Walter (1978): Begründungsprobleme der praktischen Philosophie. Stuttgart-Bad Cannstatt: Fromann-Holzboog.

Habermas, Jürgen (1991): Erläuterungen zur Diskursethik. Frankfurt a. M.: Suhrkamp. Hampshire, Stuart (1983): Morality and Conflict. Oxford: Basil Blackwell.

Hampshire, Stuart (1999): Justice is Conflict. London: Duckworth.

Herwig, Dagmar (1984): Gleichbehandlung und Egalisierung als konkurrierende Modelle von Gerechtigkeit. Eine systematische Analyse. Munich: Fink.

Kekes, John (1990): Facing Evil. Princeton: Princeton University Press.

Kekes, John (1997): Against Liberalism. Ithaca, London: Cornell University Press.

Kekes, John (2003): The Illusions of Egalitarianism. Ithaca, London: Cornell University Press. Kersting, Wolfgang (2000): Theorien der sozialen Gerechtigkeit. Stuttgart: Metzler.

Knoll, Manuel (2010): “Die distributive Gerechtigkeit bei Platon und Aristoteles”. In: Zeitschrift für Politik (ZfP) 1, pp. 3-30.

Knoll, Manuel (2013): “An Interpretation of Rawls's Difference Principle as the Principle of the Welfare State”. In: Sofia Philosophical Review 7. No. 2, pp. 5-33. 
Knoll, Manuel (2016): "The Meaning of Distributive Justice for Aristotle's Theory of Constitutions". In: ПHГH/FONS. Revista electrónica de estudios sobre la civilizatión clásica y su recepción (0JS, www.uc3 m.es/pege), Vol. 1, pp. 57-97.

Knoll, Manuel (2017a): "Platons Konzeption der Mischverfassung in den Nomoi und ihr aristokratischer Charakter". In: Knoll, Manuel/Lisi, Francisco L. (Eds.): Platons "Nomoi". Die politische Herrschaft von Vernunft und Gesetz. Staatsverständnisse 100. Baden Baden: Nomos, pp. 23-48.

Knoll, Manuel (2017b): “Aristóteles y el pensamiento político aristocrático”. Renato Cristi (Trans.). In: Revista de Filosofía 73, pp. 87-106.

Knoll, Manuel (2017c): “The Übermensch as Social and Political Task: A Study in the Continuity of Nietzsche's Political Thought”. In: Knoll, Manuel/Stocker, Barry (Eds.): Nietzsche as Political Philosopher. Berlin, Boston: De Gruyter (first published 2014), pp. $239-266$.

Krebs, Angelika (Ed.) (2000): Gleichheit oder Gerechtigkeit. Texte der neuen Egalitarismuskritik. Frankfurt a.M.: Suhrkamp.

Kymlicka, Will (2002): Contemporary Political Philosophy. An Introduction. Second edition. Oxford: Oxford University Press.

Ladd, John (Ed.) (1985): Ethical Relativism. Lanham, New York, London: University Press of America (first published 1973).

Lyotard, Jean-François (1988): The Differend. Phrases in Dispute. Georges Van Den Abbeele (Trans.). Manchester: Manchester University Press (first published Paris 1983).

Mackie, John L. (1977): Ethics. Inventing Right and Wrong. London: Penguin.

Marx, Karl (1987): A Contribution to the Critique of Political Economy. In: Marx, Karl/Engels, Friedrich: Collected Works. Vol. 29, Moscow: Progress Publishers.

Marx, Karl (2009): Critique of the Gotha Programme. London: Dodo Press.

Mill, John Stuart (2001): Considerations on Representative Government. London: Electric Book Company.

Miller, David (2003): Principles of Social Justice. Third printing. Cambridge, MA: Harvard University Press (first published 1999).

Nida-Rümelin, Julian (2016): Humanistische Reflexionen. Frankfurt a.M.: Suhrkamp.

Nietzsche, Friedrich (2005): The Anti-Christ, Ecce Homo, Twilight of the Idols, and Other Writings. Aaron Ridley/Judith Norman (Eds.); J. Norman (Trans.). Cambridge Texts in the History of Philosophy. Cambridge: Cambridge University Press.

Nozick, Robert (1974): Anarchy, State, and Utopia. Oxford: Basic Books.

Nussbaum, Martha (2011): Creating Capabilities. The Human Development Approach. Cambridge: Belknap Press of Harvard University Press.

Plato (1997): Laws. T.J. Saunders (Trans.). In: Plato, Complete Works. J.M. Cooper (Ed.). Indianapolis, Cambridge: Hackett.

Pojman, Louis P./Fieser, James (2012): Ethics. Discovering Right and Wrong. Seventh edition. Belmont, CA: Wadsworth Cengage Learning.

Polansky, Ronald (1991): “Aristotle on Political Change”. In: Keyt, David/Miller, Fred D. Jr. (Eds.): A Companion to Aristotle's "Politics", Cambridge, Oxford: Blackwell, pp. $322-345$.

Rawls, John (1971): A Theory of Justice. Cambridge, MA: Belknap Press of Harvard University Press. 
Rawls, John (2005): Political Liberalism. Expanded edition. New York: Columbia University Press.

Rawls, John (2007): Lectures on the History of Political Philosophy. Samuel Freeman (Ed.). Cambridge, MA, London: Belknap Press of Harvard University Press.

Ribeiro, Brian (2011): “Philosophy and Disagreement”. In: Crítica. Revista Hispanoamericana de Filosofía 43. No. 127, pp. 3-25.

Siegel, Harvey (2013): “Argumentation and the Epistemology of Disagreement”. In: OSSA Conference Archive, Paper 157.

Sommer, Andreas Urs (2016): Werte. Warum man sie braucht, obwohl es sie nicht gibt. Stuttgart: Metzler.

Waldron, Jeremy (1999): Law and Disagreement. Oxford: Oxford University Press.

Walzer, Michael (1983): Spheres of Justice. A Defense of Pluralism and Equality. New York: Basic Books.

Warnke, Claudia (1993): Justice and Interpretation. Cambridge, MA: MIT Press.

Weber, Max (1949): “The Meaning of 'Ethical Neutrality' in Sociology and Economics”. In: Weber, Max: On the Methodology of the Social Sciences. Edward Shills/Henry Finch (Trans. and Eds.). Glencoe, IL: The Free Press of Glencoe. 
